TAPROBANICA, ISSN 1800-427X. June, 2014. Vol. 06, No. 01: pp. 55.

(C) Research Center for Climate Change, University of Indonesia, Depok, Indonesia \& Taprobanica Private Limited, Homagama, Sri Lanka http://www.sljol.info/index.php/tapro

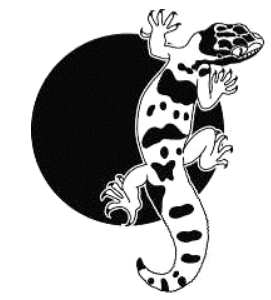

\section{Hemidactylus treutleri from Eastern Ghats, Andhra Pradesh, India}

The genus Hemidactylus is represented by 25 species in India (Mirza \& Sanap, 2014). Hemidactylus treutleri Mahony, 2009 was described from the Golconda Fort, Hyderabad, Andhra Pradesh. Since Mahony in 2009 only one new locality has been reported, at Rishi Valley, Tirupathi foothills, Andhra Pradesh (Sreekar et al., 2010). On 11 December 2012 at 13:43 $\mathrm{h}$ we found an individual of Hemidactylus treutleri (Fig. 1) on a rocky surface at Peddagattu village $\left(16^{\circ} 36^{\prime} 23.86^{\prime \prime} \mathrm{N}\right.$, 79¹4'14.19"E), Nalgonda District, Andhra Pradesh. This was during the project of "Base line studies on flora and fauna of the Lambapur, proposed for uranium mining" which was funded by Board of Research and Nuclear Sciences (BRNS). The individual was identified using the diagnosed characters stated in Mahony (2009). The location lies in a biodiversity rich zone of the Eastern Ghats and the habitats mostly consist of dry deciduous forest composed largely of herbs together with a few shrubs and rarely trees and thorn forests. The other sympatric Hemidactylus gecko species recorded include $H$. frenatus, $H$. brooki, and Hemidactylus leschenaultii. The present record is $130 \mathrm{~km}$ away from the type locality of Mahony (2009) and $336 \mathrm{~km}$ away from the second record of Sreekar (2010).

\section{Acknowledgements}

We express our sincere thanks to BRNS for funding, Golusu Baburao (Care Earth Trust) for species identification and Kalaimani for valuable comments. Finally we would like to thank Stephen Mahony for reviewing the manuscript.

\section{Literature Cited}

Mahony, S., 2009. A new species of gecko of the genus Hemidactylus (Reptilia: Gekkonidae) from Andhra Pradesh, India. Russian Journal of Herpetology, 16: 27-34.
Mirza, Z. A. and R. Sanap, 2014. A new cryptic species of gecko of the genus Hemidactylus Oken, 1817 (Reptilia: Gekkonidae) from Southern India. Taprobanica, 6 (1): 12-20.

Sreekar, R., S. Deodhar, Y. Kulkarni, 2010. Predation on Hemidactylus treutleri (Squamata: Gekkonidae) by the peninsular rock agama Psammophilus dorsalis (Squamata: Agamidae) in Rishi Valley, Andhra Pradesh, India. Herpetology Notes, 3: 33-35.

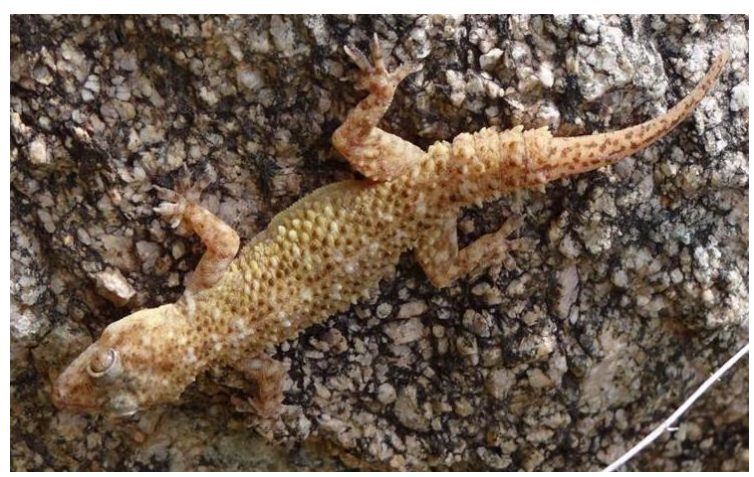

Figure 1: Hemidactylus treutleri recorded from Peddagattu, Nalgonda District, Andhra Pradesh.

Submitted: 22 Mar. 2014, Accepted: 23 Apr. 2014 Section Editor: John Rudge

B. L. Narayana ${ }^{1,2}$, G. Surender ${ }^{1} \&$ V. V. Rao ${ }^{1}$

${ }^{1}$ All India Network Project On Agricultural Ornithology, ANGR Agricultural University, Rajendera Nagar, Hyderabad 500030, Andhra

Pradesh, India ${ }^{2}$ E-mail: narayana.laxmi8@gmail.com 